\title{
LITERATURA E HISTÓRIA: O ROMANCE REVOLUCIO- NÁRIO DE ANDRÉ MALRAUX
}

MARIA TERESA DE FREITAS

Espécie de modelo de análise de obras literárias que tratam de temas históricos, esse ensaio examina as relações entre História e Literatura, tomando como exemplo os dois romances de André Malraux sobre a Revolução Chinesa de 1925-1927. Les Conquérants (1928) e La Condition Humaine (1933). A análise toma como ponto de partida a pesquisa histórica, isto é, a confrontação dos romances com textos documentais que fornecem dados comprovadamente reais sobre o assunto, com o objetivo de verificar como e por que um escritor utiliza e manipula esses dados para organizá-los sob forma de romance.

Considerada a situação peculiar desse tipo de romance, onde o universo fictício se insere numa realidade referencial anterior a ele, de existência comprovada e facilmente reconhecivel la História, cujos temas são de domínio públicol, o estudo é conduzido em quatro etapas: num primeiro momento, examina-se o aspecto especificamente documental dos romances, que, a partir de dados precisos e autênticos, operam uma verdadeira reconstituição da situação histórica em questão. A seguir, focaliza-se o con-
São Paulo, Atual Editora, 1986

junto de elementos fictícios, mostrando a dimensão sóciohistórica que eles adquirem nos romances: trata-se aqui de uma análise sociológica da ficção literária. Na terceira parte, penetra-se no plano propriamente estético do estudo, onde se examina a transformação da realidade histórica em realidade estética, isto é, da História em Literatura, bem como os objetivos dessa transformação. Num quarto e último passo, é analisado o caráter mítico que a manipulação literária empresta ao acontecimento histórico: estamos no plano do enfoque ideológico a que esse tipo de romance se prestam freqüentemente; ao transformar os horrores da guerra nas belezas da emoção estética e transcendental, o autor erige uma verdadeira apologia da Revolução, através da qual tenta atingir a sensibilidade das massas e contribuir para a formação das consciências. A conclusão que se impõe é que a $\mathrm{Li}$ teratura pode oferecer à História uma solução metafísica como resposta aos conflitos que esta impinge ao individuo: percebe-se aqui uma concepção essencialista e idealista da arte - o mito da criação artística - que, influente, intemporal e internacional, possibilita ao 
homem dominar o universo e sobreviver à morte.

Trata-se principalmente aqui de mostrar a importância do texto literário, não apenas como forma de conhecimento, mas também como meio de ação, sem que para isso se perca a autonomia de criação artistica que lhe é inerente: se a expressão individual assume uma dimensão social - o que permite a abordagem sóciohistórica dos romances - ela é também e principalmente fruto de uma determinada consciência literária e criação de um estilo particular - no caso, o revolucionário, onde o idealismo estético se impõe e predomina.

Além de constituir importante reflexão sobre um mo-

mento histórico de importância capital em nosso século, esta obra fornece interessantes instrumentos para a análise do fenômeno histórico-literário, apresentando inovações aos métodos de teoria literária, na medida em que se insere no campo das pesquisas interdisciplinares.

Num momento de crises ameaçadoras como o que vivemos atualmente, uma análise tão sensivel dos horrores da Revolução e da necessidade do restabelecimento de determinados valores, como a que faz Malraux nesses romances, bem merece um ensaio que evidencie sua pertinência e suas repercussões.

\section{POESIA ARCÁDICA PORTUgUeSA}

\section{LÊNIA MÁRCIA DE MEDEIROS MONGELLI}

Coleção Literatura e Perspectiva, São Paulo, Global, 1986

Fazendo parte de programa mais amplo, sob direção do Prof. Dr. Massaud Moisés, esta obra pretende oferecer uma visão de conjunto da poesia do Arcadismo em Portugal.

Com este intuito, seleciona textos nem sempre facilmente encontráveis, de autores muitas vezes desconhecidos do grande público, como João Xavier de Matos, Filinto Elisio, Marquesa de Alorna etc. Em que pese a homogeneidade de visão de mundo típica dos poetas da se- gunda metade do século XVIII, a seleção permite detectar a nota distintiva de cada um, conduzindo à realidade pluriforme, prenhe de contradições, cujo centro é ocupado pela Revolução Francesa.

Os textos selecionados vêm precedidos e/ou acompanhados de: a) uma "Introdução" substancial, onde o Arcadismo é visto, de perspectiva histórica, na Europa e em Portugal; e, de perspectiva estilística, em seus componentes estéticos 